\title{
The Revelation of Philippine Labor Exporting Experiences in the Context of the Belt and Road
}

\author{
Jingyan Duan \\ International Business School \\ Yunan University of Finance and Economics \\ Kunming, P. R. CHINA \\ 20025859@qq.com
}

\author{
Dan $\mathrm{Lu}^{*}$ \\ Yunan University of Finance and Economics \\ School of Finance and Public Management \\ Kunming, P. R. CHINA \\ yufejennyludan@126.com
}

\begin{abstract}
In the background of the Belt and Road, China get more opportunities to export surplus labors to other countries. However, there are many issues about labor exporting management and administration. As the biggest labor exporting country around the world, the Philippines has exported labors since 1960s, and it has rich experience about how to manage and assistant labor exporting. Therefore, this paper will research and analysis the Philippines labor exporting experience, and then it will give suggestions to solve relevant current issues.
\end{abstract}

Key Words - the Belt and Road; labor exporting; current issues; The Revelation

\section{INTRODUCTION}

Same as china, The Philippines is a developing country, which was named as "Asian Four tigers" with Indonesia, Malaysia and Thailand in the 1990s. However, the 1997 Asian economic crisis causes the Philippines economy into a tailspin, and the Philippines recovered gradually until 2010. The Philippines' overall economic developing speed is not as fast as China currently, but the development of the Philippines's tertiary industry is better than China. The tertiary industry is $54.6 \%$ of the national economy in the Philippines, the development of service industry is mature, especially labor exporting. The Philippines labor exporting started at the beginning of the 20th century, and it has been the largest labor exporting country since 1960s. The population of labor exporting is increasing steadily, because of the following characteristics, more exporting direction countries, multi-levels of exporting labor, perfect exporting labor service law system, and effective organization and management. As the largest labor exporting country, the Philippines not only had very rich experiences in labor exporting, but also developed it as the foreign exchange industry. The management of this industry is very standard and humanization, from recruitment, which follows regulations of recruitment, training, legal protection, and other legal problems solving [1].

\section{LABOR EXPERIENCES OF THE PHILIPPINES}

The Philippines is the top one country of labor exporting, about $10 \%$ of national population working overseas to earn more than $\$ 12.8$ billion pre-year, which support and promote the development of the domestic economy effectively. China can learn from The Philippines about comprehensive management of labor exporting, training, policy support and legal protection.

\section{A. More Exporting Destinations and Number of Labors}

According to the data from Philippines Statistics Authority, the Philippines exported labor 24.47 million, including 11.97 million males and 12.5 million females in 2015. The exporting destinations are throughout five continents around the world.

According to the table above, the Philippines exported 83.9\% labor to Asia, and most labors was exported to Western Asia, about $56.3 \%$. Besides, about $16.6 \%$ labor was exported to East Asia, and $1.1 \%$ labor was exported to Southeast Asia and South Asia. Except Asia, the Philippines exported labor $7.1 \%$ to Europe, and $6.1 \%$ to the Americas. All above, the labor exporting proportion of the Philippines is no more than $10 \%$ in different areas, except West Asia and East Asian.

\section{B. Multi-levels of the Exporting Labor}

The Philippines Statistics Authority issued Distribution of Overseas Filipino Workers by Major Occupation Group over the years, which shown that the multi-levels of labor exporting have been formed for years. According to statistics, the proportion of service and sales workers decreased from $37.8 \%$ in 2003 to $17.6 \%$ in 2015 . In addition, the proportion of skilled works reached $66.7 \%$, and the unskilled workers is about $33.3 \%$ in 2015 .

The Philippines Statistics Authority issued Distribution of Overseas Filipino Workers by Major Occupation Group over the years, which shown that the multi-levels of labor exporting have been formed for years. According to statistics, the proportion of service and sales workers decreased from $37.8 \%$ in 2003 to $17.6 \%$ in 2015 . In addition, the proportion of skilled works reached $66.7 \%$, and the unskilled workers is about $33.3 \%$ in 2015 . 


\begin{tabular}{|c|c|c|c|c|}
\hline \multicolumn{2}{|r|}{ Aare } & $\%$ & Male & Female \\
\hline \multicolumn{2}{|r|}{ Africa } & 1.1 & 1.9 & 0.4 \\
\hline \multirow{4}{*}{ East Asia } & Hong Kong & 5.9 & 0.8 & 10.7 \\
\hline & Japan & 3.5 & 5.1 & 1.9 \\
\hline & Taiwan & 4.5 & 3.8 & 5.2 \\
\hline & Other counties (including China \& Korea) & 2.8 & 4.1 & 1.5 \\
\hline \multirow{3}{*}{ Southeast Asia and South Asia } & Malaysia & 3.3 & 3.3 & 3.4 \\
\hline & Singapore & 5.7 & 3.8 & 7.5 \\
\hline & Other countries & 2.0 & 2.4 & 1.7 \\
\hline \multirow{5}{*}{ West Asia } & Kuwait & 5.8 & 1.8 & 9.6 \\
\hline & Qatar & 5.5 & 6.4 & 4.6 \\
\hline & Saudi Arabia & 24.7 & 31.7 & 18.0 \\
\hline & United Arab Emirates & 15.5 & 12.2 & 18.6 \\
\hline & Other countries & 4.7 & 2.2 & 7.1 \\
\hline \multicolumn{2}{|r|}{ Australia } & 1.6 & 2.2 & 1.0 \\
\hline \multicolumn{2}{|r|}{ Europe } & 7.1 & 10.3 & 4.1 \\
\hline \multicolumn{2}{|c|}{ North America and South America } & 6.1 & 7.8 & 4.6 \\
\hline \multicolumn{2}{|c|}{ Other countries } & 0.1 & 0.2 & - \\
\hline
\end{tabular}

\begin{tabular}{|c|c|c|}
\hline Major Occupation Group & $\begin{array}{c}\text { Population } \\
\text { (Thousand) }\end{array}$ & $\begin{array}{c}\text { Proportion } \\
(\%)\end{array}$ \\
\hline Managers & 758.6 & 3.1 \\
\hline Professionals & 2324.7 & 9.5 \\
\hline Technicians and associate \\
professionals & 1590.6 & 6.5 \\
\hline
\end{tabular}




\begin{tabular}{|c|c|c|}
\hline Clerical support workers & 1321.4 & 5.4 \\
\hline Service and sales workers & 4306.7 & 17.6 \\
\hline Craft and related trades workers & 2887.5 & 11.8 \\
\hline Plant and machine operators and assemblers & 3132.2 & 12.8 \\
\hline Elementary occupations & 8148.5 & 33.3 \\
\hline Total & $\mathbf{2 4 , 4 7 0}$ & - \\
\hline
\end{tabular}

\section{Well-established Legal System}

In the early 1900s, the Philippines set the relevant law and regulations to protect for migrant workers. These labor exporting laws and regulations have following features.

\section{1) Rigorous and practical legal system}

The code style laws and Anglo-American system laws constitute the Philippine relevant overseas labor laws. The former includes Constitution and Labor Law, and the latter includes Overseas Labor and Overseas Filipino law and Overseas Labor Administration Seafarers' Recruitment of Employment Regulations. The former laws set basic system, rights and legal status systematically of the Philippine overseas labor, which clearly defined roles and responsibilities of the government to protect labor rights and interests overseas, and how to manage and get license for labor exporting institutions. The latter legislated specific and practical details about overseas labor recruitment, assignment, license issuing, regulatory, social security, cost sharing, and relief fund.

\section{2) Perfect legal system}

The Philippines issued Act of Republic 2468 when the large-scale overseas employment boom occurred in 1915, which regulated ways and methods of managing recruiting and exporting workers overseas. According to the international macro environment and the change of the domestic economic situation, the Philippines formed the completed legal system by issuing, modifying, and improving relevant laws during the labor exporting developing period. The overseas labor law system takes Constitution as the core, and adopts Labor Law as the basement.

\section{3) Matched domestic laws and international rules}

The Philippines created international conventions, and the protection and enforcement mechanisms to protect Filipino working overseas in international conferences. In addition, the Philippines government signed bilateral or multilateral agreements with different exporting countries or areas to guarantee working condition, labor protection, and social security of oversea workers.

Furthermore, the Philippines based on international rules to formulate relevant overseas labor laws. For example, based on the international labor standards, the Philippines government setup Labor Law. Therefore, the Philippines oversea labor laws showed international characteristics as legal origin, forms, and contents [2].

\section{Effectively Organizing and Managing Labor Exporting}

The sustainable growth of the Philippine overseas labor market contacted with policy encourage, governmental organizing, managing, and coordinating oversea workers. The following are approaches of how the government manages labor exporting affairs.

\section{1) Suitable organization management and departments}

The Philippine government established complete and effective system from the central to the local administrative region, which in charge of organizing, administrating and supervising labor exporting affairs. The overseas employment supervising agencies are mainly composed of the Department of Foreign Affairs (DFA) and the Department of Labor and Employment (DOLE). The overseas affairs office of DFA takes the responsibilities of protecting overseas labor rights, and evaluating human rights situation and under the international and regional human rights system. In addition, DFA set up labor affairs counsellors and secretaries in labor importing countries. DOLE has two branches, which includes the Philippines Overseas Employment administration (POEA) and the Overseas Workers welfare Administration (OWWA).

Furthermore, president of the Philippines employ overseas labor affairs consultant give advices and suggestions about overseas labor service markets development, and labor exporting strategies.

\section{2) High targeted regulations}

The Philippine government departments of labor export management are very comprehensive, including recruitment, training, international travelling, job searching, and conflicts solving. Each aspect has strict rules and specific management measures. For example, the Philippine government set rules about over 18 years old women working abroad, which should be able to cope with complex situations.

\section{3) Specification of the private labor exporting agencies}

According to the government statistics, the private labor exporting agencies exported $95 \%$ workers of the total output labors in recent years. The government decreased exporting agencies from 1023 in 1983 to 642 in 1990 by standardized management. 
POEA supervised both the relevant government departments and the private labor exporting agencies about exporting activities and whole process by charging guarantee deposit and heavy fines, which can manage exporting affairs effectiveness and efficiency.

\section{MEASURES to AdDress Problems ABove}

The Belt and Road initiative involves 64 countries and more than a hundred cities, including labor exporting countries in Southeast Asia and South Asia, and labor demanded countries, such as the Central Asia, Western Asia and Europe. Therefore, to solve the existing problems, exporting surplus labor by The Belt and Road initiative would be an effective way to create economic benefits as well as social benefits.

\section{A. Increase the Number of Exporting Labors and Destinations}

To increase the number of labors and destinations, it is essential to be brave enough to Go-out. According to The Belt and Road economic development strategy, the Chinese government should positively seek cooperation opportunities in international labor market, and directly contact customers in importing countries to obtain the first-hand information on market demands. In addition, a stable network can be built to expand the sources of information and exporting ways by finding and cooperating with the reputable human resources institutions in importing countries with large labor import.

The Internet is the basis for managing talent pool and collecting market information. Now, the world has entered the big data age, so it is very useful and popular to adopt big data pool to analysis and know the talent information. Designing Chinese and English bilingual website pages for labor services agencies can provide employment information, labor exporters, political regulations, and experience introduction for the job seekers. Besides, it can also provide vacancy information for the labor demand markets to establish a network between such a large number of applicants and employers.

\section{B. Expand the Structural Hierarchy of Labor Services Export}

Expanding the hierarchy of labor services export is an effective way to increase the number of exporting workers and destinations. In industries and positions which are scarce in foreign countries but with comparative advantages in China. According to guidance of foreign employers or labor agents, Chinese agencies can recruit and export personnel, such as the accounting, nursing staffs, Chinese medicine practitioners, acupuncturist, cooks, food processing personnel, and electricians, which short in the United Kingdom, Australia, and New Zealand. Besides, Chinese cooks are short in German, and Chinese teachers are short in Southeast Asian countries. According to the needs of foreign labor market, integrating the comparative advantages can not only achieve the targets of increasing both the labor services exporting hierarchy and the number of expatriate workers and destinations, but also enhance China's competitiveness in the market.

\section{Complete Relevant Laws}

In view of the existing legal problems, China should learn from the Philippines. The Philippines based on its national constitution to formulate laws, such as Foreign Project Contracting and Labor Services Cooperation Management Law, and Overseas Employment Promotion Law. China also can base on New Labor Contract Law to supplement relevant legal regulations, which can identify the illegal behaviors in aspects including organizing, exporting and protecting oversea labors, as well as punishment or convictions of these actions in laws or regulations.

China government should adopt the margin system to encourage agencies to comply with relevant laws and regulations. The margin system can increase the entry threshold of agencies, and also can strengthen the punishments on the offending institutions. The national legislation is the only way to show the importance of labor exporting, and it is the valid approach to punish illegal activities of exporting agencies.

In addition, the relevant laws and regulations should protect the rights and interests of the both pre-exporting and overseas workers. The relevant laws and regulations shall specify the responsibility and obligations of agencies when overseas workers encounter life threats, labor disputes, unfair wages and other urgent situations. Besides, agencies should provide assistance in the specified time, otherwise it will be held accountable for their inaction and severely punished.

\section{Strengthen the Organization and Services of Labor Exporting}

The significant issue of China labor export is organizing confusion. In order to eradicate a series of existing problems, China should tackle them from following aspects, such as setting up institutions rationally, enhancing service awareness, and pre-travel training.

Firstly, the government should set up institutions rationally. The Ministry of Commerce and the Ministry of Human Resources and Social Security should set up the management department together for exporting labor, which should take responsibility to organize, manage and supervise all kinds of affairs. The new set up department need to coordinate the basic functions of sub-departments to avoid the adverse situations, such as conflicts of functions and matters unattended. The effectiveness and efficiency managerial system should be established from the central to local governments completely.

In addition, the Ministry of Foreign Affairs should set up the labor services managerial department in Chinese embassies and consulates around the world, which focus on the labor services exporting affairs, such as the exploration of labor markets, protection of exported labors, and settlement of labor dispute. The above-mentioned managerial departments will promote efficiency and effectiveness of oversea labor management, and it will protect their rights and interests, if the above method carried out effectively.

Finally, the governmental department need to improve the service awareness to provide necessary services and 
assistance for the exporting process, such as posting recruitment information, providing information proved

\section{CONCLUSION}

To sum up, there are both business opportunities and challenges in the International Labor Markets. Therefore, it is necessary to follow The Belt and Road initiative to solve current labor exporting problems. The above solutions and countermeasures will improve competitive advantages in oversea labor markets. This not only alleviates the domestic employment pressure, but also increases the recognition and economic benefits of China's labor exporting. service, problems solving assistance, and urgent help.

\section{ACKNOWLEDGEMENT}

This paper is sponsored by Yunnan Province Department of Education Research Project No. 2011Y021. Some data and information of this paper is from Pro. Yong Yu. Therefore, thanks for all helps.

\section{REFERENCES}

[1] Y. Yang, "The successful experience of the Philippines domestic service exporting," Theoretical Research. vol. 51, pp. 178-179, 2014.

[2] L. Wei, "Analysis and reference of the Philippines overseas labor law system," Academic Forum, Vol. 5, pp. 105-111, 2015. 